\title{
Clinical practice guidelines in the diagnosis and management of acute pancreatitis
}

\section{Wytyczne dotyczące praktyki klinicznej w zakresie diagnostyki i leczenia ostrego zapalenia trzustki}

\author{
Hiroyuki Kinoshita1, Jianhua Zhang², Aroon Ponthisarn³, Manoj Kumar Sharma4, Nguyen Quang Binh5, \\ Alex Leow Siam ${ }^{6}$, Chandika Samaranayake ${ }^{7}$, Arnold Darnindro ${ }^{8}$, Michael Barnes ${ }^{9}$ \\ 'Department of Gastroenterology and Hepatology, Graduate School of Medical Sciences, Kyushu University, Fukuoka City, Japan \\ 2Department of Gastroenterology, The First Affiliated Hospital of Nanchang University, Nanchang, China \\ ${ }^{3} \mathrm{Gl}$ and Liver Centre, Bangkok Medical Centre, Bangkok, Thailand \\ ${ }^{4}$ Department of Gastroenterology, Postgraduate Institute of Medical Education and Research, Chandigarh, India \\ ${ }^{5}$ Department of Gastroenterology, Cho Ray Hospital, Ho Chi Minh City, Vietnam \\ ${ }^{6}$ Division of Gastroenterology and Hepatology, University of Malaya, Kuala Lumpur, Malaysia \\ ${ }^{7}$ Department of Gastroenterology, Hemas Southern Hospital, Wattala, Sri Lanka \\ ${ }^{8}$ Department of Internal Medicine, Fatmawati General Hospital, Jakarta, Indonesia \\ ${ }^{9}$ Department of Gastroenterology, Faculty of Medicine, University of Queensland, Brisbane, Australia \\ Asian Pacific Gastroenterology \& Hepatology Association
}

Key words: diagnosis, management, acute pancreatitis, evidence-based recommendations, clinical practice guidelines.

Słowa kluczowe: diagnostyka, leczenie, ostre zapalenie trzustki, zalecenia oparte na dowodach naukowych, wytyczne dotyczące praktyki klinicznej.

\begin{abstract}
Acute pancreatitis (AP) continues to be a cause of significant morbidity and mortality and requires more research to identify the best clinical management practices. Many guidelines have been proposed for the initial management of AP. Although these guidelines have a significant overlap in the recommendations provided for diagnosing and managing AP, there is still some disagreement in aspects of the types and timing of interventions that should be used for the diagnosis and management of both mild and severe AP. A working group consisting of physicians, especially gastroenterologists from various hospitals and universities from the Asia-Pacific region, has led to the development of these evidence-based guidelines and recommendations. Early enteral feedings, performing a cholecystectomy in the case of gallstones if indicated during the initial hospitalisation, treatment of hypertriglyceridaemia-induced acute pancreatitis using intravenous regular insulin or plasmapheresis if severe, and providing counselling for alcohol avoidance are recommended.
\end{abstract}

\section{Streszczenie}

Ostre zapalenie trzustki nadal charakteryzuje się dużą zachorowalnością i śmiertelnością. Niezbędne są dalsze badania, które pozwolą na bardziej szczegółowe opracowanie optymalnej praktyki w zakresie postępowania u pacjentów z tym schorzeniem. Dotychczas przedstawiono wiele wytycznych dotyczących schematu początkowego postępowania w przypadku ostrego zapalenia trzustki. Chociaż pod względem zalecanej diagnostyki i postępowania wytyczne te w znacznym stopniu się pokrywają, nadal istnieje pewna rozbieżność poglądów na temat rodzaju oraz czasu interwencji, które powinny być podejmowane $\mathrm{w}$ diagnostyce i terapii łagodnych i ciężkich postaci ostrego zapalenia trzustki. W ramach grupy roboczej złożonej z lekarzy, głównie gastroenterologów, z różnych szpitali i uniwersytetów w regionie Azji i Pacyfiku opracowano niniejsze wytyczne i zalecenia oparte na dowodach naukowych. Zaleca się wczesne wdrażanie żywienia drogą dojelitową, cholecystektomię u chorych z kamicą żółciową, jeżeli istnieje takie wskazanie podczas wstępnej hospitalizacji, leczenie ostrego zapalenia trzustki wywołanego hipertriglicerydemią przy zastosowaniu standardowej, dożylnie podawanej insuliny lub (w ciężkich przypadkach) plazmaferezy, a także poradnictwo dotyczące unikania alkoholu. 


\section{Introduction}

The yearly global incidence rate of acute pancreatitis (AP) is 34 cases per 100,000 people in the general population. AP hospitalisations account for more than 275,000 per year in the United States (US). More than 2.6 billion dollars are spent on caring for patients with AP in the US [1]. Poland has the highest incidence rate of AP among European countries, estimated to be 72.1 per 100,000 patients per year [2]. Many of these cases require hospital admission, and severe cases require admission to an intensive care unit (ICU). The mortality rates range from $2 \%$ to $16 \%$, depending on the severity of the illness. Despite the burden of illness, many questions remain regarding the management and complications. Many guidelines for management have been proposed for the initial management of AP. Many of these recent recommendations come from guidelines issued by the American Gastroenterological Association, the International Association of Pancreatology, and other gastroenterological associations around the world $[1,3,4]$.

A systematic review of the available literature published between 2005 and 2018 revealed more than 15 clinical practice guidelines in the diagnosis and management of AP. Although these guidelines have a significant overlap in the recommendations provided for diagnosing and managing AP, there is still some disagreement regarding the types and timing of interventions that should be used for the diagnosis and management of both mild and severe AP [5-7]. The availability of newer imaging studies and minimally invasive to noninvasive therapies have also changed clinical medical practice. Recent studies about the clinical management of AP have shown that there are important areas of noncompliance with evidence-based recommendations despite the availability of guidelines. This underscores the importance of the need to create understandable and implementable recommendations for the diagnosis and management of AP, and it emphasises the need for regular audits of clinical practice within a given hospital to ensure compliance.

The purpose of the present clinical practice guideline is to provide evidence-based recommendations for the management of AP as well as the management of hypertriglyceridaemia-induced pancreatitis and the complications of AP.

\section{Methodology}

A group of nine physicians, researchers, and gastroenterologists working on pancreatitis and related disorders from various hospitals and universities from the Asia-Pacific region, who are members of the Asian Pacific Gastroenterology \& Hepatology Association have formed a pancreatitis workgroup and have led to the development of these evidence-based guidelines and recommendations. All these guidelines are developed using the standard processes, guiding principles, and styling outlined in the Clinical Practice Management
Guidelines Resource Guide. This includes recruitment strategies and expectations for workgroup composition, management of conflict of interest and disclosure for participating workgroup members, evidence grading resources, literature review techniques, required approval from bodies, and suggestions for implementation.

\section{Methods used to collect the evidence}

The following criteria were strictly used by the author(s) of the guidelines and workgroup committee members to conduct searches in PubMed, Embase, the Cochrane library, and clinical trial electronic databases for the collection of material and evidence for review. Literature sources were as follows: hand-searching journals, external guidelines, and conference publications.

\section{Methods to select the evidence}

Leading medical journals, professional society publications, external guidelines, and conference publications. Inclusion criteria were: (1) randomised or observational cohort studies, including systematic reviews, meta-analyses, and literature reviews on patients with AP focusing on the specific study questions; (2) studies published in English language; and (3) available in full text. Exclusion criteria were: (1) non availability of full text; (2) studies on patients with 'acute on chronic pancreatitis'; (3) non-randomised studies prior to 1993 (i.e. publication of the initial Atlanta classification); and (4) case reports.

\section{Methods used to formulate the recommendations}

The members of the workgroup agreed to adopt the recommendations developed by external organisations and/or created internal recommendations via a consensus approach using a discussion of the literature and expert opinion/experience. If controversies or issues arose because consensus could not be reached, the topic was escalated appropriately as per the guiding principles outlined in the Clinical Practice Guidelines Resource Guide.

\section{Methods used to assess the strength of the recommendations/quality of the evidence}

Recommendations developed internally, or those adopted from external resources without an assigned evidence-based grade, were evaluated by the guidelines workgroup using an algorithm that was adapted from the Grading of Recommendations Assessment, Development, and Evaluation (GRADE) methodology [8].

\section{GRADE Strength of evidence}

High: high level of confidence that the effect of the study reflects the actual effect. 
Table 1. Summary and grading of diagnostic recommendations in acute pancreatitis

\begin{tabular}{|c|c|c|}
\hline Diagnostic recommendations & Strength of evidence & Guideline recommendation \\
\hline $\begin{array}{l}\text { A serum lipase level should be checked in all patients } \\
\text { with a suspected diagnosis of acute pancreatitis (AP) }\end{array}$ & Moderate-high & Strong \\
\hline $\begin{array}{l}\text { C-reactive protein (CRP) levels should be assessed at } \\
\text { the time of admission and daily for the first } 72 \mathrm{~h} \text { after } \\
\text { admission }\end{array}$ & Low-moderate & Weak \\
\hline $\begin{array}{l}\text { Acute Physiology and Chronic Health Evaluation } \\
\text { (APACHE) II scores should be calculated at the time of } \\
\text { admission to assess for severity and every } 24 \mathrm{~h} \text {, } \\
\text { at least for the first } 72 \mathrm{~h} \text { after initial admission }\end{array}$ & Moderate & Weak \\
\hline $\begin{array}{l}\text { Correct diagnosis of AP should be made in all patients } \\
\text { within } 48 \mathrm{~h} \text { of admission }\end{array}$ & Low-moderate & Weak \\
\hline $\begin{array}{l}\text { Ultrasound (US) to exclude biliary aetiology like gallstones } \\
\text { or stones in common bile duct (CBD), especially if there } \\
\text { are concerning lab results, such as elevated liver enzymes } \\
\text { and elevated direct bilirubin are present }\end{array}$ & High & Strong \\
\hline $\begin{array}{l}\text { Computed tomography (contrast-enhanced) if } \\
\text { concerns about severe pancreatitis, such as necrotising } \\
\text { pancreatitis, are present and the patient has no } \\
\text { contraindications to contrast use }\end{array}$ & Low-moderate & Strong \\
\hline $\begin{array}{l}\text { Magnetic resonance cholangiopancreatography (MRCP) } \\
\text { use in early AP }\end{array}$ & Low-moderate & Weak \\
\hline
\end{tabular}

Moderate: study confidence that the effect in the study is close to the actual effect, but it might also be possible that it is substantially different.

Low: the actual effect of the study may differ significantly from the estimate.

Very low: the exact effect of the study is likely to be substantially different from the estimated effect.

\section{Classification}

Pancreatitis can be classified into two major categories: Acute inflammation without necrosis (interstitial oedematous pancreatitis) and necrotising pancreatitis with peripancreatic or pancreatic tissue necrosis. The severity of AP can be classified as: 1) mild (no signs of any organ failure); 2) moderate (transient organ failure for less than $48 \mathrm{~h}$ ); or 3) severe (organ failure for greater than $48 \mathrm{~h}$ ). Various severity scoring systems have been developed (for their utility) for AP, but SIRS (systemic inflammatory response syndrome) criteria or APACHE II (Acute Physiology and Chronic Health Evaluation) score are considered superior [9].

\section{Diagnosis of acute pancreatitis}

Initial clinical evaluation of the patient should include organ failure assessment. Laboratory and diagnostic analysis should include complete blood count (CBC), chemistries, calcium, triglycerides, and lactic acid levels. Measurement of amylase and lipase can be useful for the initial diagnosis, but they are not useful follow-up markers and are not useful in predicting the severity or prognosis. Patients with severe AP with significant underlying comorbid diseases, cardiorespiratory organ failure, coma, or significant acid-base or electrolyte abnormalities need ICU admission. Table 1 provides a summary and grading of diagnostic recommendations in AP.

Two out of the following three criteria are required for the diagnosis of AP.

1) Abdominal pain: epigastric in location, radiating to the back, associated with vomiting and nausea.

2) Amylase and lipase levels that are three times the upper limit of normal level for the lab's normal reference range (Note: every lab has different reference ranges) [10]. Amylase levels can be falsely elevated in conditions such as parotitis, intestinal obstruction, intestinal infarction, renal failure, macroamylasaemia, ruptured ectopic pregnancy, alcoholism, and cirrhosis. Nonspecific elevation of lipase levels can be seen in diabetes mellitus type 2 , diabetic keto acidosis, cirrhosis, inflammatory bowel disease, celiac disease, bowel obstruction, or infarction [11].

a) Lipase levels are more specific for AP than amylase levels [12].

b) Lipase stays elevated for a longer time.

c) Lipase levels without amylase levels are sufficient to help diagnose AP.

d) The degree of elevation of lipase has NO prognostic value and does NOT predict the severity of the AP.

3) Imaging findings that support the diagnosis of AP include oedema, peripancreatic fluid, peripancreatic fat stranding, etc. [13]. 
a) Ultrasound (US) - to exclude biliary aetiology, especially if there are other concerning lab results such as elevated liver enzymes and elevated direct bilirubin. US helps to determine if the patient has any gallstones and/or a stone in the common bile duct (CBD).

b) Computed tomography (contrast-enhanced) - recommended if there is concern of severe pancreatitis, such as necrotising pancreatitis. Unless there is a contraindication (e.g. renal dysfunction), intravenous contrast should be used to assess for pancreatic necrosis once patients are adequately volume resuscitated, and normovolaemia is restored [14].

c) Magnetic resonance cholangiopancreatography (MRCP) - mostly valuable after the resolution of AP to assess any changes in the ducts in the pancreas several weeks after an attack. MRCP is only recommended in patients in whom there is an elevation of hepatic enzyme levels and in whom the CBD is found to be normal or is not visualised adequately on ultrasound. However, the higher cost of MRCP should limit its use in underdeveloped or developing countries in the diagnosis of acute cholecystitis or gallstones, especially with the availability and utility of ultrasonography for the same purpose [15]. Follow-up CT scan or MRI in AP is only indicated when there is a lack of clinical improvement or if there is clinical deterioration, or especially when invasive intervention is considered.

Additional supportive and diagnostic laboratory evaluation [16]:

d) Liver panel and bilirubin - helps determine aetiology.

e) Calcium level-hypocalcaemia is usually seen in AP.

f) Triglyceride level-levels greater than $1000 \mathrm{mg} / \mathrm{dl}$ can lead to the diagnosis of hypertriglyceridaemia-induced pancreatitis. g) C-reactive protein (CRP) inflammatory marker CRP increases steadily in relation to the severity of AP and hence is an inexpensive way to measure it, and testing is readily available in most laboratories [17].

h) APACHE II scores should be calculated at the time of admission, to assess for severity, and then daily, at least for the first $72 \mathrm{~h}$ after initial admission. A score of 8 or higher at baseline on admission or in the first $72 \mathrm{~h}$ on APACHE II is suggestive of severe AP and is predictive of a worse clinical outcome [18].

i) A straightforward clinical severity assessment tool called BISAP has appeared recently [14]. The following five criteria are used: 1) blood urea nitrogen greater than $25 \mathrm{mg} / \mathrm{dl}$; 2) impaired mental status (Glasgow coma scale score less than 15); 3) SIRS score higher than or equal to 2 ; 4 ) age greater than 60 years; and 5) pleural effusion.

BISAP has been developed using the data from about 18,000 patients with AP. It has been prospectively analysed and found to be as accurate as APACHE II in predicting the severity and mortality of AP. The most significant advantage of this scoring system is the ease of its usage and application in day to day practice [19].

\section{Management}

Initial management is supportive with intravenous fluids, nil per os, pain management, and later on, introduction of nutritional support. Unfortunately, the best practice guidelines for some of these elements of patient care remain unclear. Please admit to adult medicine service or consult GI service on admission. Table 2 provides a summary and grading of management recommendations in AP.

Table 2. Summary and grading of management recommendations in acute pancreatitis

\begin{tabular}{|c|c|c|}
\hline Treatment recommendations & Strength of evidence & Guideline recommendation \\
\hline $\begin{array}{l}\text { Supportive care with intravenous fluids, pain management, and } \\
\text { early mobilisation from the mainstay of treatment in mild acute } \\
\text { pancreatitis (AP) }\end{array}$ & Low & Strong \\
\hline $\begin{array}{l}\text { Early enteral nutrition (within } 48 \mathrm{~h} \text { ) is recommended in patients } \\
\text { with severe AP }\end{array}$ & High & Strong \\
\hline Routine use of prophylactic antibiotics is not recommended in AP & High & Strong \\
\hline Obstructive gallstone AP - ERCP is recommended within 24 to $48 \mathrm{~h}$ & Moderate-high & Strong \\
\hline $\begin{array}{l}\text { Management of pancreatic pseudocysts is usually non-emergent } \\
\text { when they are not symptomatic }\end{array}$ & Moderate & Strong \\
\hline $\begin{array}{l}\text { Cholecystectomy should be performed during the index } \\
\text { admission in patients who have mild AP and delayed until } \\
\text { clinical resolution in patients who have severe AP }\end{array}$ & Moderate & Strong \\
\hline $\begin{array}{l}\text { Initial management of hypertriglyceridaemia-induced acute } \\
\text { pancreatitis (HTGP) includes regular intravenous insulin }\end{array}$ & Moderate & Strong \\
\hline $\begin{array}{l}\text { Treatment for severe HTGP with signs of organ failure includes } \\
\text { apheresis/plasmapheresis }\end{array}$ & Moderate & Strong \\
\hline
\end{tabular}




\section{Fluids}

Evidence suggests that aggressive intravenous fluid replacement in the first 12 to $24 \mathrm{~h}$ (initial stages) is associated with mortality reduction [20]. A study suggested that the use of Ringer's lactate may reduce the incidence of SIRS when compared to normal saline [21].

A systematic review was conducted by Haydock et al. to analyse fluid management in AP. Fifteen studies were identified and met the inclusion criteria. Nine of these studies compared aggressive versus nonaggressive fluid resuscitation and were split into two groups of five and four regarding the best management approach. In two of these selected studies, researchers tried using different goals (use of goal-directed therapy): one study revealed clinical benefit, and one study did not.

Consensus on which type of crystalloid to use remains unclear. Both Ringer's lactate and saline have been used but have not been head to head compared in large randomised trials. The exception in these cases is hypercalcaemia-induced AP, where lactated Ringer's is not recommended for management because it contains $3 \mathrm{mEq} / \mathrm{l}$ calcium [22]. Fluids containing hydroxyethyl starch are also not recommended.

Despite this lack of clear clinical guidance, many medical practitioners initially start with aggressive intravenous fluid resuscitation with a goal of urine output of at least $0.5 \mathrm{ml} / \mathrm{kg} / \mathrm{h}$, while carefully watching for any signs of volume overload or depletion. Frequently monitoring vital signs, urine output measurement, and daily labs, including haemoglobin and blood urea nitrogen, can help in adjustments to the rate of fluids administration. Serum glucose levels should be frequently monitored and treated because hyperglycaemia is commonly associated with an increased rate of secondary infection of the pancreas. If the patient is oliguric despite the aggressive intravenous fluid resuscitation, then the possibility of abdominal compartment syndrome should be considered, and the transduction of bladder pressures is recommended [22].

\section{Nutrition}

Traditionally, bowel rest was initially recommended to avoid pancreatic exocrine function stimulation, but this is no longer the case. Early enteral nutrition (within $48 \mathrm{~h}$ ) is recommended and is thought to help maintain gut mucosa and decrease the translocation of bacteria. A systematic review conducted by Vaughn et al. identified nine trials that compared feeding early versus late in AP [23]. The researchers found no difference in the mortality rates with early feeding but noted that a worsening pancreatic necrosis trend and multiple organ failure was observed with the delayed feeding.

In a study of randomised, controlled trials comparing total parenteral nutrition with enteral feeding,
Yi et al. found evidence that enteral feeding is superior, with less multiple organ failure, less mortality, fewer infections, and less peripancreatic necrosis [24]. In patients who cannot take peroral nutrition, nasojejunal or nasogastric feeding should be initiated with a low-fat, high protein, semi-elemental formula that will minimise the amount of enzyme stimulation from the pancreas.

Contraindications to enteral nutrition include ileus, compartment syndrome, and complex fistulae. However, necrotising pancreatitis is not a contraindication to enteral nutrition.

Parenteral nutrition can be considered if enteral intake has been unsuccessful (more emesis than intake, dehydration) for a period of 2-3 days. Dehydration and malnutrition have been associated with poor outcomes and more complications [25]. Peripheral or central routes can be used. There is no evidence to suggest that intralipids are contraindicated.

\section{Pain management}

There is no consensus on the appropriate pain medication regimen. Consult the pain team if the pain is difficult to control with opioids after the first $48 \mathrm{~h}$. Acetaminophen or NSAIDs, such as ibuprofen or ketorolac, are appropriate if there are no contraindications. Morphine has no contraindication to use in AP. It had been suspected that morphine could cause sphincter of Oddi spasm, but this has not been proven. Hydromorphone or fentanyl may be considered if morphine is not available or if the pain is too severe and not controlled with morphine $[26,27]$.

\section{Antibiotic use}

Routine use of prophylactic antibiotics is not recommended, even in severe AP. It is one of the most controversial areas of discussion. Fungal infection is not uncommon in patients with necrotising pancreatitis, especially after antibiotic therapy. That is another reason to avoid the liberal use of prophylactic antibiotics; fungal infection would naturally increase morbidity and delay recovery [28, 29]. Twenty percentage of patients with AP develop extrapancreatic infections. In randomised, controlled trials on the use of antibiotics prophylactically for severe necrotising pancreatitis, no difference was observed in mortality nor in peripancreatic or pancreatic rates of infection. There was no significant difference in the development of single organ or multiple organ failures or changes in the length of hospital stay. Based on this research, prophylactic antibiotics are not routinely used for AP [30].

Use of antibiotics in AP is only recommended: a) for documented infected necrosis; b) when necrosis is present, and patient is clinically deteriorating, febrile; and c) if gas collections are present on imaging [31]. Antibiotic choices (those that penetrate into necrotic 
tissue) include carbapenem, quinolones, and metronidazole [28].

\section{Timing of invasive surgeries/procedures}

In a systematic review comparing emergent endoscopic retrograde cholangiopancreatography (ERCP) to conservative management in acute gallstone pancreatitis there was no difference observed in organ failures, mortality, infection, or total occurrence rates of development of necrotising pancreatitis. As a result, emergent ERCP is not routinely recommended for gallstone-induced AP. Some exceptions to this are in cases of acute cholangitis when ERCP is indicated regardless of the presence of $\mathrm{AP}$, and in cases in which a visible CBD (common bile duct) obstruction is seen on imaging.

There has been intense debate regarding the timing of cholecystectomy in acute gallstone-induced AP. Van Baal et al. conducted a meta-analysis and systematic review and found that early intervention points to fewer late complications from gallstones, while a delayed approach was safer and perhaps associated with better clinical outcomes because of decreased inflammation seen in the surgical site bed [9]. A randomised trial included in the study revealed evidence that cholecystectomy performed during the initial admission is associated with significant reductions in gallstone-related complications and mortality, with no increase in conversion from a laparoscopic to an open cholecystectomy or surgical difficulty. Based on these findings, early cholecystectomy has been recommended [32]. Recommended guidelines include:

a) Obstructive gallstone AP - ERCP is recommended within 24 to $48 \mathrm{~h}$ [33].

b) Mild gallstone AP - cholecystectomy should be performed during the index admission. It is essential that all patients with acute biliary pancreatitis undergo laparoscopic cholecystectomy within 2-4 weeks of resolution of AP. If not done, there is a $30 \%$ probability of recurrence of AP within the next 3 months [32].

c) Abdominal compartment syndrome - an emergent surgical consultation is recommended [34].

d) Pancreatic necrosis - if persistent, we would recommend to wait preferably $>4$ weeks before surgery is considered. Early pancreatic necrosectomy results in increased morbidity and mortality [35]. The preferred procedure is endoscopic or percutaneous necrosectomy [35, 36].

e) Management of pancreatic pseudocysts is usually non-emergent when they are not symptomatic. Pancreatic pseudocysts usually develop and mature over many weeks and can resolve spontaneously on their own in several weeks or months. There is no acute indication to involve surgery unless it causes significant mass effect [37].

\section{Hypertriglyceridaemia-induced pancreatitis}

The main treatment modalities for the initial management of hypertriglyceridaemia are apheresis and insulin [38]. However, randomised trials comparing their efficacy are lacking. Initial management of patients with hypertriglyceridaemia-induced pancreatitis includes treatment of AP and reduction of serum triglyceride levels to $<500 \mathrm{mg} / \mathrm{dl}(5.6 \mathrm{mmol} / \mathrm{l})$ [39]. In patients with Hypertriglyceridaemia-induced pancreatitis (serum triglyceride level $>1000 \mathrm{mg} / \mathrm{dl}$ plus lipase $>3$ times the upper limit of normal) and signs of hypocalcaemia, lactic acidosis, signs of worsening systemic inflammation or organ dysfunction, or multi-organ failure, treatment with apheresis, specifically therapeutic plasma exchange, is recommended. Triglyceride levels should be monitored during every cycle of apheresis. We recommend continuation of apheresis until triglyceride levels are below $<500 \mathrm{mg} / \mathrm{dl}$ $(5.6 \mathrm{mmol} / \mathrm{l})$.

In patients without worrisome features, we recommend initiating therapy with intravenous (IV) regular insulin. Triglyceride levels should be monitored every $12 \mathrm{~h}$. Serum glucose should be measured every hour, and the insulin/5\% dextrose infusion should be adjusted accordingly. Intravenous insulin should be stopped when triglyceride levels are $<500 \mathrm{mg} / \mathrm{dl}$ (5.6 mmol/l) [40].

Once triglyceridelevels are $<500 \mathrm{mg} / \mathrm{dl}(5.6 \mathrm{mmol} / \mathrm{l})$, patients with hypertriglyceridaemia-induced pancreatitis require long-term therapy to prevent recurrent pancreatitis and to prevent other complications of hypertriglyceridaemia. This consists of both pharmacologic therapy (e.g. oral gemfibrozil $600 \mathrm{mg}$ twice daily) and dietary modification (e.g. fat- and simple sugar-restricted diet) [40].

\section{Discharge criteria}

The patient can be safely discharged when the following criteria are met: a) pain controlled with oral medications; b) enteral or oral intake is sufficient for hydration and nutrition, and there is no need for IV fluid support; and c) outpatient follow-up has been arranged with a primary care provider, GI service, and surgery if biliary surgery is needed.

\section{Prognosis}

Most patients with AP will improve within oneweek of conservative management and be well enough for discharge [41]. The aetiology should be identified, and a plan to prevent recurrence should be initiated before hospital discharge. Long-term prognosis is based on the aetiological factor and patient compliance with lifestyle modifications [42]. AP generally resolves and leaves pancreatic function intact. Many patients progress to recurrent AP or chronic 
pancreatitis, and the risk is higher among smokers, alcoholics, and men [43].

\section{Alcohol avoidance intervention}

There are few research studies evaluating the effect of alcohol counselling in patients with alcoholinduced AP. The results of one trial showed overall lower readmission rates, but no change in the rate of recurrent AP. A review of a brief alcohol intervention in a primary care setting showed a significant reduction in alcohol consumption, a finding that persisted in a follow-up meta-analysis. Thus, a brief alcohol counselling intervention is recommended in cases of alcohol-induced AP [44].

\section{Conclusions}

AP continues to be a cause of significant morbidity and mortality and needs more research to better identify the best clinical management practices. Current recommendations include avoiding TPN and prophylactic antibiotics. Early enteral feedings, performing a cholecystectomy in case of gallstones if indicated during the initial hospitalisation, treatment of HTGP using IV insulin or plasmapheresis if severe, and providing counselling for alcohol avoidance are recommended. A lower degree of certainty exists on how to provide initial fluid resuscitation (including which type of intravenous fluid to use), what rate to administer them, and what goal to aim for. Hopefully, these questions will be answered by proper quality trials in the near future.

\section{Conflict of interest}

The authors declare no conflict of interest.

\section{References}

1. Crockett S, Falck-Ytter Y, Wani S, Gardner TB. Acute pancreatitis guideline. Gastroenterology 2018; 154: 1102.

2. Kozieł D, Głuszek S. Epidemiology of acute pancreatitis in Poland - selected problems. Med Stud 2016; 32: 1-3.

3. IAP/APA evidence-based guidelines for the management of acute pancreatitis. Pancreatology 2013; 13: e1-e15.

4. Rosołowski M, Lipiński M, Dobosz M, Durlik M, Głuszek S, Kuśnierz K, Lampe P, Małecka-Panas E, Nowakowska-Duława E, Nowak-Niezgoda M, Radomańska B, Talar-Wojnarowska R, Wereszczyńska-Siemiątkowska U, Rydzewska G. Management of acute pancreatitis (AP) Polish Pancreatic Club recommendations. Gastroenterology Rev 2016; 11: 65-72.

5. Loveday BPT, Srinivasa S, Vather R, Mittal A, Petrov MS, Phillips AR, Windsor JA. High quantity and variable quality of guidelines for acute pancreatitis: a systematic review. Am J Gastroenterol 2010; 105: 1466-1476.

6. Aly EAH, Milne R, Johnson CD. Non-compliance with national guidelines in the management of acute pancreatitis in the United Kingdom. Dig Surg 2002; 19: 192-198.

7. Mofidi R, Madhavan KK, Garden OJ, Parks RW. An audit of the management of patients with acute pancreatitis against national standards of practice. Br J Surg 2007; 94: 844-848.

8. Guyatt GH, Oxman AD, Vist GE, Kunz R, Falck-Ytter Y, Alonso-Coello P, Schünemann HJ; GRADE Working Group. GRADE: an emerging consensus on rating quality of evidence and strength of recommendations. BMJ 2008; 336: 924-926.

9. Balthazar EJ. Acute pancreatitis: assessment of severity with clinical and CT evaluation. Radiology 2002; 223: 603-613.

10. Gwozdz GP, Steinberg WM, Werner M, Henry JP, Pauley C. Comparative evaluation of the diagnosis of acute pancreatitis based on serum and urine enzyme assays. Clin Chim Acta 1990; 187: 243-254.

11. Hameed AM, Lam VWT, Pleass HC. Significant elevations of serum lipase not caused by pancreatitis: a systematic review. HPB 2015; 17: 99-112.

12. Keim V, Teich N, Fiedler F, Hartig W, Thiele G, Mössner J. A comparison of lipase and amylase in the diagnosis of acute pancreatitis in patients with abdominal pain. Pancreas 1998; 16: 45-49.

13. Anemone S, Uyeda JW. Patient-friendly summary of the ACR appropriateness criteria: right upper quadrant pain. J Am Coll Radiol 2019 pii: S1546-1440(19)31186-X. doi: 10.1016/j.jacr.2019.09.014.

14. Benarroch-Gampel J, Boyd CA, Sheffield K, Townesn Jr CM, Riall TS. Overuse of computed tomography in patients with complicated gallstone disease. Gastroenterology 2011; 213: 524-530.

15. Romagnuolo J, Bardou M, Rahme E, Joseph L, Reinhold C, Barkun AN. Magnetic resonance cholangiopancreatography. Ann Intern Med 2003; 139: 547-557.

16. Uhl W, Büchler M, Malfertheiner P, Martini M, Beger HG. PMN-elastase in comparison with CRP, antiproteases, and $\mathrm{LDH}$ as indicators of necrosis in human acute pancreatitis. Pancreas 1991; 6: 253-259.

17. Wilson C, Heads A, Shenkin A, Imrie CW. C-reactive protein, antiproteases and complement factors as objective markers of severity in acute pancreatitis. Br J Surg 1989; 76: $177-181$.

18. Lankisch PG, Warnecke B, Bruns D, Werner HM, Grossmann F, Struckmann K, Brinkmann G, Maisonneuve P, Lowenfels AB. The APACHE II score is unreliable to diagnose necrotizing pancreatitis on admission to hospital. Pancreas 2002; 24: 217-222.

19. Gao W, Yang HX, Ma CE. The value of BISAP score for predicting mortality and severity in acute pancreatitis: a systematic review and meta-analysis. PLoS One 2015; 10: $\mathrm{e} 0130412$.

20. Gardner TB, Vege SS, Chari ST, Petersen BT, Topazian MD, Clain JE, Pearson RK, Levy MJ, Sarr MG. Faster rate of initial fluid resuscitation in severe acute pancreatitis diminishes in-hospital mortality. Pancreatology 2009; 9: 770-776.

21. Wu BU, Hwang JQ, Gardner TH, Repas K, Delee R, Yu S, Smith B, Banks PA, Conwell DL. Lactated Ringer's solution reduces systemic inflammation compared with saline in patients with acute pancreatitis. Clin Gastroenterol Hepatol 2011; 9: 710-717e711.

22. Haydock MD, Mittal A, Wilms H, Phillips A, Petrov MS, Windsor JA. Fluid therapy in acute pancreatitis - anybody's guess. Pancreatology 2013; 13: e33. 
23. Vaughn VM, Shuster D, Rogers MAM, Mann J, Conte ML Saint S, Chopra V. Early versus delayed feeding in patients with acute pancreatitis: a systematic review. Ann Intern Med 2017; 166: 883-892.

24. Yi F, Ge L, Zhao J, Lei Y, Zhou F, Chen Z, Zhu Y, Xia B. Meta-analysis: total parenteral nutrition versus total enteral nutrition in predicted severe acute pancreatitis. Intern Med 2012; 51: 523-530.

25. Chang YS, Fu HQ, Xiao YM, Liu JC. Nasogastric or nasojejunal feeding in predicted severe acute pancreatitis: a meta-analysis. Crit Care 2013; 17: R118.

26. Basurto Ona X, Rigau Comas D, Urrútia G. Opioids for acute pancreatitis pain. Cochrane Database Syst Rev 2013; 7: CD009179.

27. Meng W, Yuan J, Zhang C, Bai Z, Zhou W, Yan J, Li X. Parenteral analgesics for pain relief in acute pancreatitis: a systematic review. Pancreatology 2013; 13: 201-206.

28. Villatoro E, Bassi C, Larvin M. Antibiotic therapy for prophylaxis against infection of pancreatic necrosis in acute pancreatitis. Cochrane Database Syst Rev 2010; 5: CD002941.

29. Bai Y, Gao J, Zou DW, Li ZS. Prophylactic antibiotics cannot reduce infected pancreatic necrosis and mortality in acute necrotizing pancreatitis: evidence from a meta-analysis of randomized controlled trials. Am J Gastroenterol 2008; 103: 104-110.

30. Lim CL, Lee W, Liew YX, Tang SS, Chlebicki MP, Kwa AL. Role of antibiotic prophylaxis in necrotizing pancreatitis: a meta-analysis. J Gastrointest Surg 2015; 19: 480-491.

31. Ukai T, Shikata S, Inoue $M$, Noguchi $Y$, Igarashi $H$, Isaji S, Mayumi T, Yoshida M, Takemura YC. Early prophylactic antibiotics administration for acute necrotizing pancreatitis: a meta-analysis of randomized controlled trials. J Hepatobiliary Pancreat Sci 2015; 22: 316-321.

32. van Baal MC, Besselink MG, Bakker OJ, van Santvoort HC, Schaapherder AF, Nieuwenhuijs VB, Gooszen HG, van Ramshorst B, Boerma D; Dutch Pancreatitis Study Group. Timing of cholecystectomy after mild biliary pancreatitis: a systematic review. Ann Surg 2012; 255: 860866.

33. Lee YT, Chan FKL, Leung WK, Chan HL, Wu JC, Yung MY, $\mathrm{Ng}$ EK, Lau JY, Sung JJ. Comparison of EUS and ERCP in the investigation with suspected biliary obstruction caused by choledocholithiasis: a randomized study. Gastrointest Endosc 2008; 67: 660-668.

34. Miranda CJ, Siriwardena AK. The incidence of abdominal compartment syndrome in severe acute pancreatitis. HPB 2016; 18: e782.

35. Bradley EL, Allen K. A prospective longitudinal study of observation versus surgical intervention in the management of necrotizing pancreatitis. Am J Surg 1991; 161: 19-25.

36. Mier J, León EL, Castillo A, Robledo F, Blanco R. Early versus late necrosectomy in severe necrotizing pancreatitis. Am J Surg 1997; 173: 71-75.

37. Cantasdemir M, Kara B, Kantarci F, Mihmanli I, Numan F, Erguney S. Percutaneous drainage for treatment of infected pancreatic pseudocysts. South Med J 2003; 96: 136-140.

38. Click B, Ketchum AM, Turner R, Whitcomb DC, Papachristou GI, Yadav D. The role of apheresis in hypertriglyceridemia-induced acute pancreatitis: a systematic review. Pancreatology 2015; 15: 313-320.
39. He WH, Yu M, Zhu Y, Xia L, Liu P, Zeng H, Zhu Y, Lv NH. Emergent triglyceride-lowering therapy with early high volume hemofiltration against low-molecular-weight heparin combined with insulin in hypertriglyceridemic pancreatitis. J Clin Gastroenterol 2016; 50: 772-778.

40. Rawla P, Sunkara T, Thandra KC, Gaduputi V. Hypertriglyceridemia-induced pancreatitis: updated review of current treatment and preventive strategies. Clin J Gastroenterol 2018; 11: 441-448.

41. Triester SL, Kowdley KV. Prognostic factors in acute pancreatitis. J Clin Gastroenterol 2002; 34: 167-176.

42. Halonen KI, Leppaniemi AK, Puolakkainen PA, Lundin JE, Kemppainen EA, Hietaranta AJ, Haapiainen RK. Severe acute pancreatitis: prognostic factors in 270 consecutive patients. Pancreas 2000; 21: 266-271.

43. Sarles H, Sarles JC, Camatte R, Muratore R, Gaini M, Guien C, Pastor J, Le Roy F. Observations on 205 confirmed cases of acute pancreatitis, recurring pancreatitis, and chronic pancreatitis. Gut 1965; 6: 545-559.

44. Kaner EF, Beyer F, Dickinson HO, Pienaar E, Campbell F, Schlesinger C, Heather N, Saunders J, Burnand B. Effectiveness of brief alcohol interventions in primary care populations. Cochrane Database Syst Rev 2007; 2: CD004148.

\section{Address for correspondence:}

Aroon Ponthisarn MD

GI and Liver Centre

Bangkok Medical Centre

Bangkok 10310, Thailand

E-mail: aponthisarn@dr.com 